\title{
Temperature reduction and local last glaciation maximum (LLGM) \\ The example of the east-Andean Cordillera around Cochabamba, Bolivia $\left(17^{\circ} \mathrm{S}\right)$
}

\author{
Samuel Imhof, Christoph Kull, Jan-Hendrik May, \\ Martin Grosjean, Heinz Veit, Berne
}

\section{Introduction}

The Central Andes of South America $\left(16^{\circ} \mathrm{S}-30^{\circ} \mathrm{S}\right)$ experienced major climatic changes during the late Quaternary, making this high altitude mountain region a key area for the study of processes and dynamics of tropical and extratropical climate variability. In the International Geosphere-Biosphere Program (IGBP), the Pole-Equator-Pole transect of the Americas (PEP I) has been analysed in detail by PAGES (Past Global Changes). The synthesis points to the climatic sensitivity of this region (MARKGRAF et al. 2000). The challenge is to disentangle local and regional influences from hemispheric or global influences and processes of past climate variability (see Kull \& GrosJean 1998).

Ice cores (Thompson et al. 1998; Thompson et al. 2003), lake sediments (Аввотt et al. 2003; Grosjean et al. 2001), hydrological, glacier and climate modeling studies (HostetTler \& ClaRK 2000; KLEIN et al. 1999; Kull et al. 2002; Seltzer 1992; Wyrwoll et al. 2000) provide quantifiable data for these environmental changes which occurred during the late Pleistocene and Holocene. The derived spatial and chronological pattern of climate variability in the western cordillera of northern Chile shows dynamical links to the extratropical westerly circulation south of $27^{\circ} \mathrm{S}$ and to the tropical influence in the northern part (KuLl et al. 2002).

The eastern cordillera north of $27^{\circ} \mathrm{S}$, situated close to the Amazon and Chaco basins, is mainly influenced by tropical circulation. There is still an ongoing debate about the chronology, the geographical extension and the related magnitude of late Pleistocene - Holocene environmental changes (BAKER et al. 2001; MOURGUiARD \& LedRu 2003; Sylvestre et al. 1999).

Due to the aridity of this high elevation mountain range, morphological structures of former lake shorelines and glacial moraines, for example, remain well preserved. An exact reconstruction of the past environment is possible. Actual annual precipitation in the center of the Arid Diagonal (Fig. 1) is about $100 \mathrm{~mm}$, with a trend to higher values towards the north, east and south. This indicates that changes in the hydrological cycle are as important as changes in the temperature regime. Recent and past glaciological conditions confirm this fact, with missing glaciations in the extremely dry Arid Diagonal and above the continuous permafrost belt (above $5500 \mathrm{~m}$ asl) being explained by lack of precipitation. Glacier dynamics, therefore, is mainly controlled by changes in the hydrological cycle (KULL et al. 2002). In the wetter areas north, south and to the east of the most arid zone, where annual precipitation reaches values of about $1000 \mathrm{~mm}$ as, for example on the eastern slope around Cochabamba, temperature (besides precipitation) plays an important role triggering glaciations. In this area, actual perennial snow cover and glaciers are limited to peaks above $5000 \mathrm{~m}$ asl. The different spatial sensitivity to moisture and/or temperature changes of glacier dynamics also influences the chronology of local maximum glacier extent in the region, making it obvious that glaciers in the Central Andean area did not reach their maximum extent at the same time in all the areas (Kull et al. 2002). Large moraine systems in the region are the residual morphological features of former glaciations. The maximum extent was reached with a lowering of the equilibrium line altidudes (ELA) by as much as 1400 m (MARK et al. 2005).

During the past years, several studies focused on the detailed reconstruction of past glaciations in the central Andean region (AmmanN et al. 2001; Kull \& Grosjean 2000; Kull et al.2003). Exposure age dating has been applied and is still in progress in order to establish a chronology of glacier advances in many parts of the Central Andes (ZeCH et al. 2006b). Furthermore, detailed studies using the mapped glaciers and subsequently applied mass balance models were successfully carried out to quantify the related past climatic conditions (KuLL et al. 2002). These activities concentrated on the western Chilean cordillera and the region of north-western Argentina, thereby encompassing the southern Altiplano (Fig. 1). Evidence for massive changes in the effective moisture regime during late glacial times due to an enhancement of the tropical circulation was found especially in the arid western cordillera between $18^{\circ} \mathrm{S}$ and $25^{\circ} \mathrm{S}$ (Betancourt et al.2000; Clayton \& Clapperton 1997; Grosjean et al. 1995; Kull \& Grosjean 2000; Placzek et al. 2006). In contrast, the westerly influenced area south of $26^{\circ} \mathrm{S}$ experienced a substantial temperature depression combined with a moderate increase in precipitation producing maximum glaciation during full glacial times, before and after the LGM (last glaciation maximum, 25-15 kyr B.P.; CAVIEDES 1990; EsPIZUA 


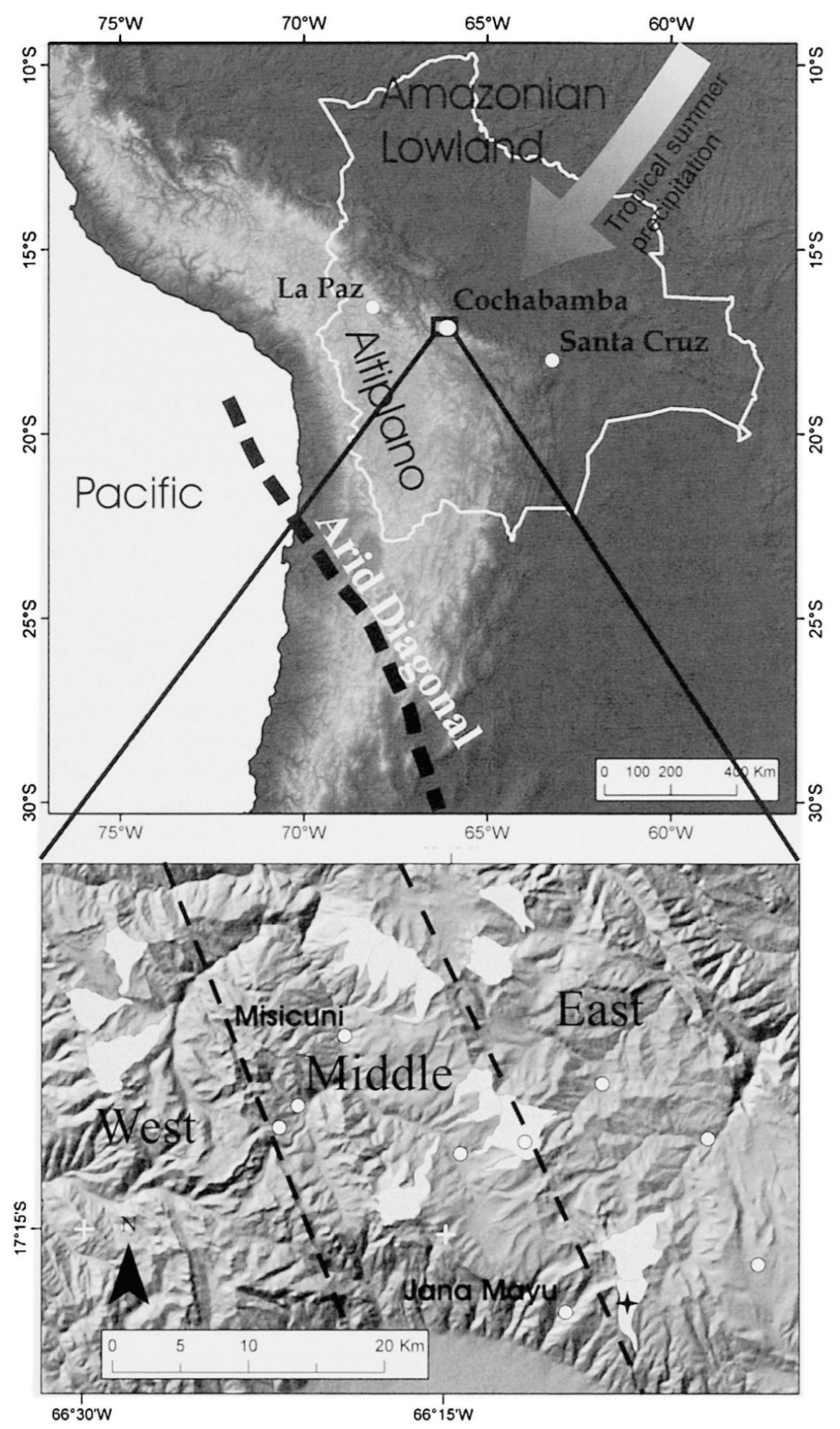

Fig. 1: Upper panel: location of the research area in the Cordillera de Cochabamba $\sim 17^{\circ} 15^{\prime} \mathrm{S} / 66^{\circ} 15^{\prime} \mathrm{W}$. Lower panel: the area has been divided into three parts to allow for the influence of mean moisture flux from the east to be taken into consideration.

The black star in the detailed map shows the paleoglacier used for 3D-modeling.

Oben: Lage des Untersuchungsgebietes in der Cordillera de Cochabamba $\sim 17^{\circ} 15^{\prime} \mathrm{S} / 66^{\circ} 15^{\prime} \mathrm{W}$. Unten: Um der allgemeinen Feuchtequelle aus Nordosten gerecht zu werden, wurde das Untersuchungsgebiet in 3 Teile unterteilt.

En haut: site de la région de recherche dans la Cordillère de Cochabamba $\left(\sim 17^{\circ} 15^{\prime} \mathrm{S} / 66^{\circ} 15^{\prime} \mathrm{W}\right)$. En bas: pour tenir compte de l'orientation nord-est des flux d'humidité, la région de recherche a été divisée en trois parties.

Source: NASA SRTM 90 m DEM 


\begin{tabular}{|lllll|}
\hline & $\begin{array}{l}\text { Precipitation (P) } \\
\left(\mathrm{mm} \mathrm{yr}^{-1}\right)\end{array}$ & $\begin{array}{l}\text { Temp. }(\mathrm{T}) \\
\left({ }^{\circ} \mathrm{C}\right)\end{array}$ & $\begin{array}{l}\text { Wind }(\mathrm{W})^{3} \\
\left(\mathrm{~m} \mathrm{~s}^{-1}\right)\end{array}$ & $\begin{array}{l}\text { Rel. hum. }(\mathrm{RH})^{3} \\
(\%)\end{array}$ \\
\hline Annual mean $(\mathrm{Ym})$ & $780-910$ & $7.0^{2}$ & 6.61 & 64 \\
Annual amplitude $(\mathrm{Ya})$ & $($ winter 108-128) & $6.4^{2}$ & 14 & 54 \\
Daily amplitude $(\mathrm{Da})$ & not def. & $16^{3}$ & not def. & not def. \\
Lapse rate $\left(100 \mathrm{~m}^{-1}\right)$ & $0^{5}$ & $-0.53^{4}(-0.7)$ & not def. & not def. \\
\hline
\end{tabular}

'see Fig. 1

${ }^{2}$ Misicuni $3750 \mathrm{~m}\left(17^{\circ} 07^{\prime} \mathrm{S}, 66^{\circ} 19^{\prime} \mathrm{W} ; 1960-80\right)$

${ }^{3} J a n a$ Mayu 3770 m $\left(17^{\circ} 18^{\prime} \mathrm{S}, 66^{\circ} 10^{\prime} \mathrm{W} ; 2002\right)$

${ }^{4}$ National Climatic Data Center (NCDC) 1980

${ }^{5}$ not significantly $>0$ !

Tab. 1: Present climatic conditions in the research area $\left(17^{\circ} \mathrm{S}\right)$

Heutige Klimabedingungen im Untersuchungsgebiet $\left(17^{\circ} \mathrm{S}\right)$

Conditions climatiques actuelles dans la zone de recherche $\left(17^{\circ} \mathrm{S}\right)$

1999; Kull et al. 2002; ZeCH et al. 2006a). In the eastern cordillera on the slope to the Amazon and Chaco basins, several glacial advances are mapped and dated to pre-LGM and late glacial times (CLAPPERTON et al. 1997; HeIne 2000; SchäbitZ 2000; Seltzer 1994; ZIPPRICH et al. 2000). There is strong evidence that LGM temperature depressions were on the order of $5-9^{\circ} \mathrm{C}$. This is shown also by STUTE et al. $(1995)\left(5^{\circ} \mathrm{C}\right)$ and Colinvaux et al. (1996) $\left(5-6^{\circ} \mathrm{C}\right)$ for the Amazonian lowlands, and in summary by HeINE $(2000)\left(5-6^{\circ} \mathrm{C}\right)$. Model results of research on north-western Argentina also indicate that maximum glaciation was triggered by massive temperature reduction and moderate humidity increase (KuLl et al. 2003)

In this study, we employ a glacier climate model to test areas around Cochabamba in order to get a detailed picture of past glacier-climate dynamics on the central eastern Andean slope.

\section{Study area and present climate}

\subsection{Study area}

The research area (Fig. 1) is located in the Cordillera de Cochabamba on the eastern slope of the Cordillera Oriental at $17^{\circ} 15^{\prime} \mathrm{S}, 66^{\circ} 15^{\prime} \mathrm{W}$. Today, the study area is free of ice, but both satellite imagery and field work evidence large moraines triggered by at least one massive glacier advance. 17 paleoglaciers, covering an altitudinal range between $3700-5000 \mathrm{~m}$ asl, were mapped in detail to obtain glaciological key parameters such as paleo-equilibrium line altitudes (paleo-ELA), accumulation area ratios (AAR), hypsographic curves and bed topography. Not only valley glaciers, but also ice caps characterized the landscape during the LLGM as the morphology of this mountain area confirms.

Exposure age dating was applied to some moraines in our study area and is described in ZECH et al. (2006b). Some of the moraines were dated to 12 and $10 \mathrm{kyr}$ B.P. These dates suggest a late deglaciation on the eastern flank of the Cordillera Oriental, reflecting results from earlier studies (Аввотт et al. 2003).

Paleo-ELA's of the last local glaciation maximum (LLGM), evidenced by the top onset of the lateral moraines, were situated between $4350-4550 \mathrm{~m}$ asl in the central and western part of the research area and at about $4250 \mathrm{~m}$ asl on the eastern slope (Fig. 1). This significant difference between the eastern and western sections of the study area points to the important role of moisture advection from the eastern lowlands and the spatial pattern of precipitation. The AARs of the former glaciers vary between 0.59-0.94. Whilst high AARs (small ablation area, i.e. short tongues) point to a wet climate with a high balance gradient in the ablation area, low AARs (around 0.6) are characteristic for cold climates and glaciers with long tongues. The observed difference in geometry and AAR may be an indication of different phases during past glacial advances. Research on this aspect is still ongoing.

\subsection{Present climate}

The present climate is dominated by dry winters and wet summers with convective precipitation originating from the tropical lowlands toward the east (Fig. 1). Local climatic data was obtained from a temperature 
station and eight precipitation gauging stations that are scattered around the study area at different altitudes (Fig. 1). Daily climatic data, although incomplete, was available from the climate station Jana Mayu (2002, $3770 \mathrm{~m}$ asl, Fig.1, Table 1).

Extrapolation of the climatic data for the formerly glaciated areas suggests annual precipitation between $780-910 \mathrm{~mm}$ and $7.0^{\circ} \mathrm{C}$ mean annual temperature at $3500 \mathrm{~m}$ asl. A summary of present climatic key parameters is given in Table 1.

Daily mean temperatures were calculated on the basis of daily minimum and maximum temperatures. These values differ by $+0.65^{\circ} \mathrm{C}$ from the «real» values, calculated from continuous measurements (Jana Mayu). This discrepancy has been corrected in the mean annual temperatures mentioned above. Free atmosphere lapse rates are derived from radiosonde measurements at $\mathrm{La} \mathrm{Paz}$ between $4050-5800 \mathrm{~m}$ asl (National Climatic Data Center, NCDC 1980). Monthly mean values vary from $-0.64^{\circ} \mathrm{C} / 100 \mathrm{~m}$ in December to $-0.42^{\circ} \mathrm{C} / 100 \mathrm{~m}$ in June and show a sinusoidal trend. Values are within the range mentioned in KaLnaY et al. (1996). Regional ground-based lapse rates were calculated from temperature stations between $2500-3700 \mathrm{~m}$ asl and show significantly higher values $\left(-0.87\right.$ to $\left.-1.07^{\circ} \mathrm{C} / 100 \mathrm{~m}\right)$. This is at least partially caused by local climates, lack of information about the exact location of stations (KAgEYAma et al. 2005) and the different altitudinal ranges considered. For this reason, two different scenarios were used for the modeling process.

Precipitation gradients were calculated from the eight precipitation stations in the study area. It should be noted that no significant positive precipitation lapse rate could be observed (multiple regression analysis). On the contrary, calculated values varied between $-3 \mathrm{~mm} / 100 \mathrm{~m}$ in the central and western parts of the study area and $-1 \mathrm{~mm} / 100 \mathrm{~m}$ in the eastern part. As a result, a value of $0 \mathrm{~mm} / 100 \mathrm{~m}$ was selected for the precipitation lapse rate in the model (Table 1).

\section{Methodology}

For the research purposes of this study, we used a glacier-climate model (Kull 1999; Kull \& GrosJEAN 2000; Kull et al. 2002; Kull et al. 2003) to reconstruct climatic conditions during LLGM in the Cordillera de Cochabamba. A detailed description of the model is provided in Kull (1999). The model is based on the actualistic principle. Fig. 2 explains the modeling procedure in a flow chart. The input parameters are:

a) present climatic parameters such as diurnal and annual cycles, amplitudes and lapse rates (Table 2), b) 3D-mapping of the former glacier geometry based on field measurements and remote sensing data (Fig. 1),

c) empirical-statistical sublimation, melt and accumulation models (Table 3).

Furthermore, the model assumes that former glaciers fulfilled the following two conditions:

I. The glaciers reached equilibrium (mass balance over the whole glacier $=0$ !). A 2D-modeling approach that fulfils this condition results in several possible temperature-precipitation scenarios.

II. Annual mass flux through a cross section in the ablation area is equal to annual mass balance below this cross section. With respective dynamical mass flux calculations derived for different cross sections, only one temperature-precipitation scenario fulfils both conditions.

The 2D-mapping is based on field work and a $30 \mathrm{~m}$ and $90 \mathrm{~m}$ digital terrain model (DTM), whereas 3D-geometrical reconstruction of the glacier bed is based on field measurements only. With the three sub-models (accumulation, sublimation, melt), the mass balance is calculated for each altitudinal belt $(100 \mathrm{~m}$ equidistance). By changing the climatic key parameters cloudiness $(\mathrm{C})$ and temperature $(\mathrm{T})$ and the dependent parameters precipitation $(\mathrm{P})$, relative humidity $(\mathrm{RH})$ and global radiation $(\mathrm{G})$, the calculation of a climate scenario is done iteratively (Fig. 2). For all modeled scenarios, the amount of winter rain appears to be the same as today and varies between $100 \mathrm{~mm}$ and $150 \mathrm{~mm}$, depending on annual precipitation. Consequently, for the scenario we assume that the main increase in annual precipitation is caused by stronger summer precipitation, a point that is also supported by field evidence (paleo-ELA distribution).

In a 2D-modeling approach (area-elevation distribution), only condition I (see above) has to be fulfilled. This leads to several temperature-precipitation scenarios. Results are especially sensitive to areaelevation distribution and vertical balance gradient $\left(\mathrm{kg} /\left(\mathrm{m}^{2 *} \mathrm{~m}\right)\right)$. Reconstruction of the former glacier surface in the ablation zone is done manually as the ice surface is given by the height of the lateral moraines. In the accumulation zone, a model (SAILER et al. 1999) is used to approximately calculate the paleo-ice surface. Especially in complex valley structures where the actual ice thickness is often under or overestimated, modeled surfaces are modified manually. For the global radiation input, a model approach is used (MöLG 2002; MöLG et al. 2003). Incoming shortwave radiation is modeled every 30 minutes for each pixel $(30 \mathrm{~m} \times 30 \mathrm{~m})$ of the reconstructed glacier surface as a function of latitude, exposition, shading, altitude and cloudiness. In the 2D-modeling scenario, all 17 glaciers 


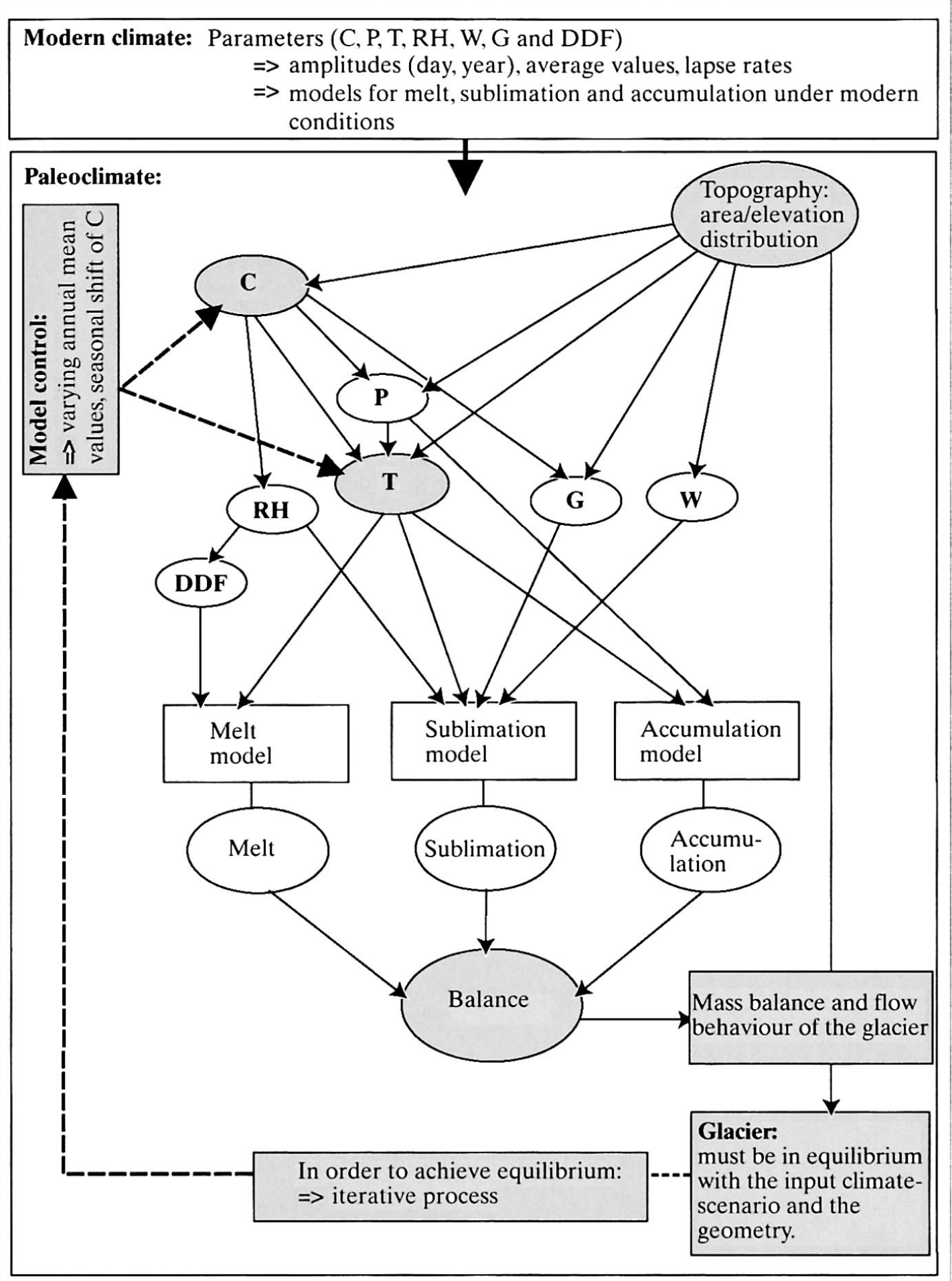

Fig. 2: Flow chart of the model: C (cloudiness), T (temperature), P (precipitation), RH (relative humidity), G (global radiation) and $\mathrm{W}$ (wind velocity)

The degree-day factor (DDF) varies with changing paleoclimatic conditions (KULL 1999). C and T are the key parameters of the model and therefore control the other climatic factors. The three submodels are based on climate transfer functions calibrated under present conditions (KuLL 1999; Table 3). The mean annual values of $\mathrm{C}$ and $\mathrm{T}$ are changed iteratively in order to reach zero mass balance and ELAs close to observed ELAs in the field.

Schema des Modellierungsablaufs: $C$ (Bewölkung), $T$ (Temperatur), $P$ (Niederschlag), RH (Relative Feuchte), $G$ (Globalstrahlung) und W (Windgeschwindigkeit)

Schéma de la modélisation: $C$ (nébulosité), $T$ (température), $P$ (précipitation), $R H$ (humidité relative), $G$ (radiation globale) et $W$ (vitesse du vent) 


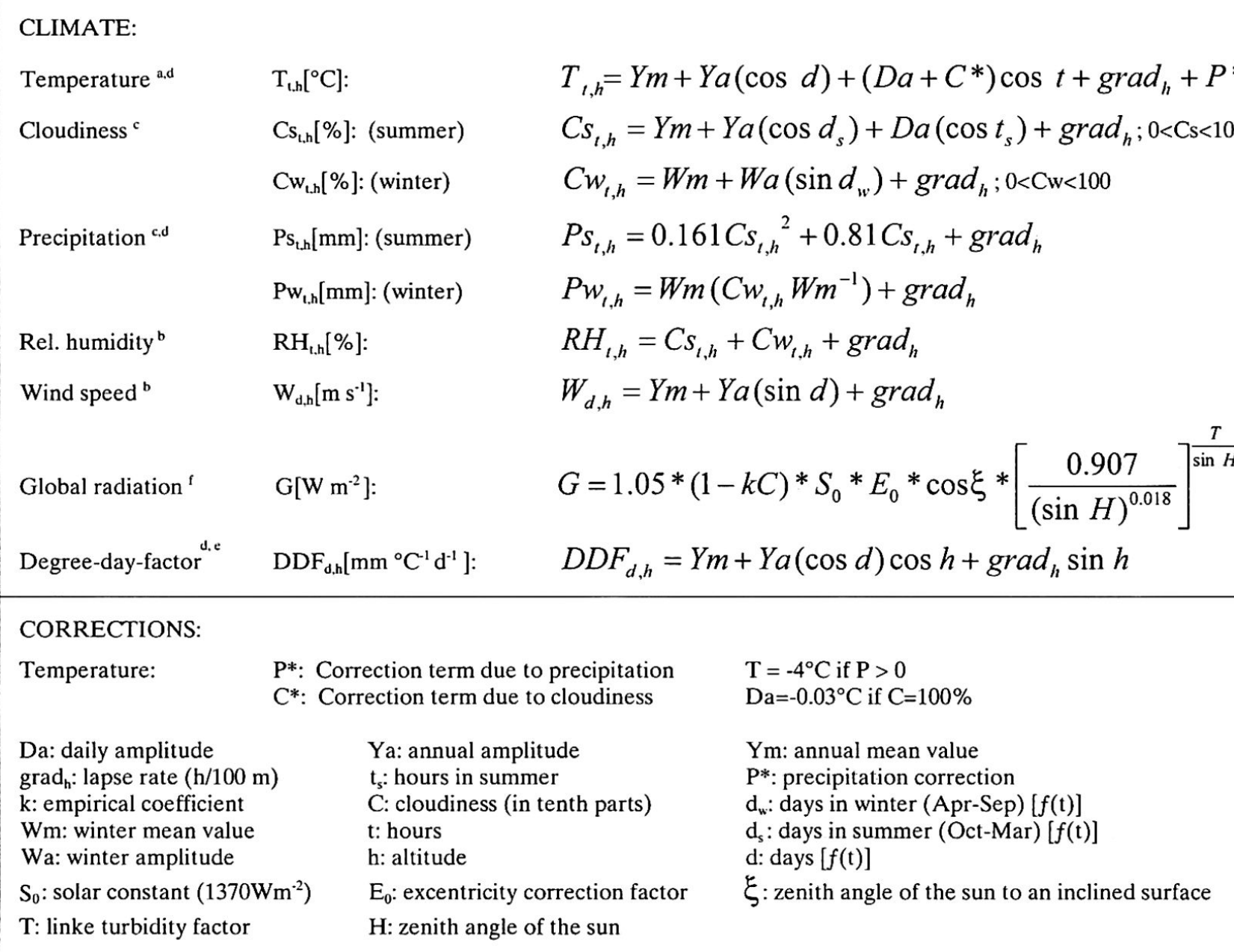

${ }^{a}$ Misicuni 3750 m (1707’S/ 66'19’W;1960-80)

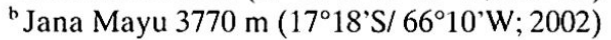

cAmmann (1996)

¿VUILLE (1996)

'SiCARD et al. (1998); WAGNON et al. (1999)

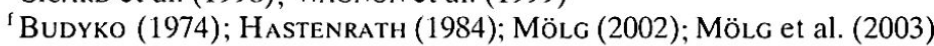

Tab. 2: Climatic parameters used in the model for daily and annual cycles and amplitudes Modellparametrisierungen für die Tages- und Jahresgänge sowie Amplituden Paramètres climatiques utilisés dans le modèle des cycles et amplitudes journalières et annuelles Quelle: Kull et al. 2002

are investigated. Two different temperature lapse rates are used in order to counteract the sensitivity of the model to this important parameter (Table 1). The first approach makes use of radiosonde measurements from La Paz, Bolivia, the second approach uses calculations based on local climatic data adjusted to take higher lapse rates during the dry season into consideration. This adjustment follows results of temperature reconstructions during LGM (or generally colder periods) in South America, which indicate that a higher temperature depression was to be found in the highlands than in the lowlands and, therefore steeper lapse rates.
This effect is typical for a dryer atmosphere during colder periods (Farrera et al. 1999; Kageyama et al. 2005; Pinot et al. 1999). For this reason, in the second approach, the assumption is made that the lapse rates during the dry season are higher.

In order to use the 3D-modeling approach (flow behavior included), at least two detailed cross sections in the ablation zone of the former maximum glaciation are necessary. Polished rock surfaces at the base of the cross sections are ideal features, as they mark the former ice basis. Unfortunately, only one glacier (Wara 


\section{MASS BALANCE:}

Sublimation $^{\text {a }} \quad$ subl $_{\mathrm{d}, \mathrm{h}}=-1.33+0.12\left(\mathrm{~W}_{\mathrm{d}, \mathrm{h}}\right)+0.24\left(\mathrm{Dd}_{\mathrm{d}, \mathrm{h}}\right)+0.27\left(\mathrm{G}_{\mathrm{d}, \mathrm{h}}\right)$

with: $\quad \mathrm{W}_{\mathrm{d}, \mathrm{h}}$ : $\max$. hourly wind velocity (daily average)

$\mathrm{Dd}_{\mathrm{d}, \mathrm{h}}$ : mean daily vapour pressure deficit

$\mathrm{G}_{\mathrm{d}, \mathrm{h}}$ : daily global radiation energy

$\left[\mathrm{mm} \mathrm{d}^{-1}\right]$

$\left[\mathrm{m} \mathrm{s}^{-1}\right]$

$\left[\mathrm{hPa} \mathrm{d}^{-1}\right]$

[W m $\left.\mathrm{W}^{-2}\right]$

Melt $^{a}$

melt $_{\mathrm{d}, \mathrm{h}}=0.97+\mathrm{DDF}_{\mathrm{d}, \mathrm{h}}\left(\mathrm{Tg}_{\mathrm{t}, \mathrm{h}}\right) ;$ for $\mathrm{Tg}>0$

with: $\quad \operatorname{Tg}_{\mathrm{t}, \mathrm{h}}$ : hourly means of the positive temperatures per day

$\left[\mathrm{mm} \mathrm{d}^{-1}\right]$

$\left[{ }^{\circ} \mathrm{C}\right]$

$\mathrm{DDF}_{\mathrm{d}, \mathrm{h}}$ : degree-day-factor, $f$ (albedo, snow density, climate)

$\left[\mathrm{mm}^{\circ} \mathrm{C}^{-1} \mathrm{~d}^{-1}\right]$

Accumulation $^{b}$

$$
a c c_{d, h}=\frac{1}{24} \sum_{t=24 d}^{24+24 d}\left(\begin{array}{lc}
P_{t, h} ; & \text { if } T_{t, h}<2 \\
\left(\frac{4-T_{t, h}}{2}\right) P_{t, h} ; & \text { if } 2 \leq T_{t, h} \leq 4 \\
0 \text { otherwise } &
\end{array}\right)
$$

with: $\quad \mathrm{P}_{t, \mathrm{~h}}$ : hourly precipitation

Specific annual

mass balance $\quad b_{h}=\sum_{d}-\left(s u b l_{d, h}+\right.$ melt $\left._{d, h}\right)+a c c_{d, h}$

a Vuille (1996)

${ }^{\mathrm{b}}$ KULL (1999)

Tab. 3: Empirical-statistical models developed for mass balance modeling Empirisch-statistische Modelle zur Massenbilanzmodellierung

Modèles empirico-statistiques développés dans la zone de recherche pour la modélisation du bilan d'équilibre Quelle: KuLl et al. 2002

Wara, black star in Fig. 1 and Fig. 3) fulfilled all abovementioned requirements, allowing for the application of dynamical ice flow calculations. Two cross sections below the paleo-ELA were measured in detail during a field trip in May 2005. A summary of the results and the uncertainties in this connection is listed in Table 4. Uncertainty in the depth of a cross section can only be positive because polished rock surfaces were found at the deepest point and therefore point to a former ice basis. Thus uncertainty arises only from underestimation of the former ice thickness (erosion of lateral moraines). The other uncertainties are related to errors in field measurement such as the reconstruction of the former glacier surfaces, slope $(\sin \alpha)$ and estimation of the flow parameters. Glacier flow is calculated after Oerlemans (1997) and BUdd (1969) with the following equations (KULL 1999):

$$
\begin{aligned}
& \begin{array}{l}
U=U_{d}+U_{s} \\
\quad=f_{d} * H^{*} \tau^{3}+\frac{f_{s} * \tau^{3}}{H} \\
\text { with } \tau=-F^{*} \rho^{*} g^{*} H^{*} \sin \alpha \\
\mathrm{f}_{\mathrm{d}}: 1.9 * 10^{-24} \mathrm{~Pa}^{-3} \mathrm{~s}^{-1} \quad \mathrm{f}_{\mathrm{s}}: 5.7 * 10^{-20} \mathrm{~Pa}^{-3} \mathrm{~m}^{2} \mathrm{~s}^{-1} \\
\rho: \text { ice density }\left(900 \mathrm{~kg} / \mathrm{m}^{3}\right) \quad \text { g: gravity }\left(9.807 \mathrm{~m} / \mathrm{s}^{2}\right)
\end{array}
\end{aligned}
$$

The calculation of the form factor $« \mathrm{~F}$ » is done after BudD (1969):

$$
F=\frac{Q}{H^{*} B}
$$

Q: area of the cross section

$\mathrm{H}$ : glacier thickness

B: hydraulic radius 

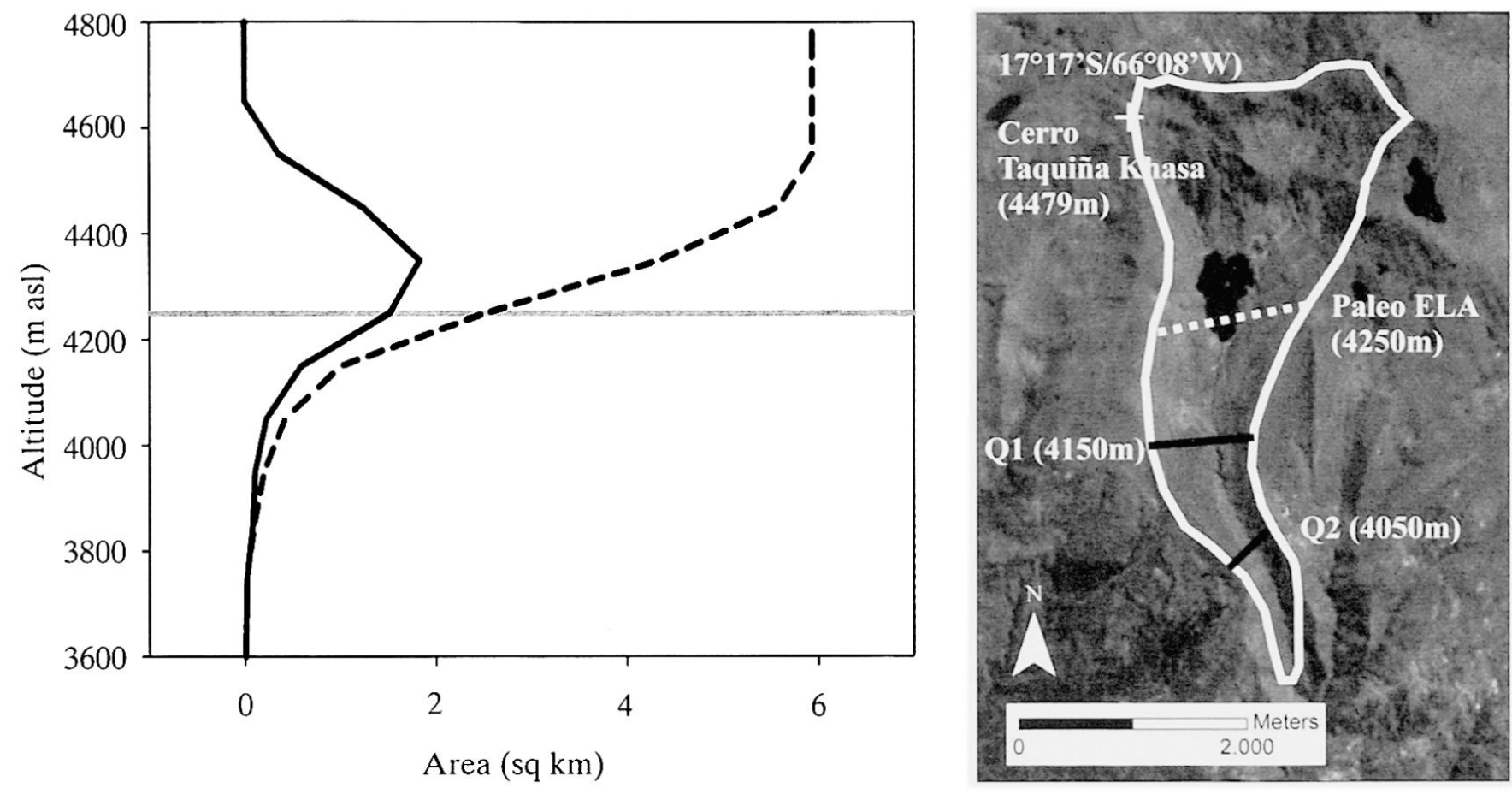

Fig. 3: Paleoglacier Wara Wara (the case-study for 3D-modeling). Left: area-elevation distribution (solid line) and cumulative glacier area. Right: photo of the former glaciated valley.

The large lateral moraines define the former ablation area in detail.

Der ehemalige Gletscher Wara Wara (Fallstudie für die 3D-Modellierung): Links: Flächen-Höhen-Verteilung (durchgezogene Linie) und die kumulierte Gletscherfä̈he mit der Höhe. Rechts: Photo des ehemaligen vergletscherten Tales.

Le paléoglacier Wara Wara utilisé pour la modélisation 3D. A gauche: distribution étendue-altitude (ligne continue) et étendue du glacier cumulée avec l'altitude. A droite: photo de la vallée anciennement glacée.

Source: NASA landsat7_233_72_tif_panchromatic

The average ice flow velocity through a given cross section allows for the calculation of the mass flux by multiplying the velocity with the cross section. In the end, the calculated climate scenario has to estimate the same negative mass balance value below the cross section as mass flux through the respective cross section.

\section{Results}

\subsection{Recent glacio-climatological conditions}

Today, the study area is not glaciated and a recent ELA has not been observed in the field. However, both satellite imagery and field work (for example, on huge moraine systems) provide evidence of large glaciations in the past. Snow fields on the south face of Cerro Tunari (about $5050 \mathrm{~m}$ asl), as seen on a field trip end of May 2005 indicate that a modern ELA would probably be not much higher than the highest peaks in the research area. MArK et al. (2005) calculates recent ELAs in the Cordillera Oriental in Bolivia at altitudes around 4980-5200 m asl (based on data from 1991-1995), the geographically closest being at $5050 \mathrm{~m}$ asl (Quimsa Cruz, $17.06^{\circ} \mathrm{S}, 67.24^{\circ} \mathrm{W}$ ) and $5100 \mathrm{~m}$ asl (Laguna Kollpa Kkota, $\left.17.43^{\circ} \mathrm{S}, 67.88^{\circ} \mathrm{W}\right)$. This information served to test the models ability to estimate present glacio-climatological conditions in the research area. Based on local climatic data (Table 1,1960-80) modeled modern ELAs varied between 5150 and $5250 \mathrm{~m}$ asl, depending on exposition, amount and annual distribution of precipitation. The modeled results correspond with those observed in the field. The calculated present annual and seasonal balances are shown in Fig. 4. The ability of the model to calculate present values correctly made it possible to use the same model for assessing past glaciation events.

\subsection{D-Results}

In the 2D-modeling approach, all 17 glaciers were investigated. Results derived with the higher lapse rate scenario (Table 1) are summarized in Fig. 5. All possible temperature-precipitation scenarios that fulfill condition I of the model are shown. A clear difference in reconstructed mean climatic conditions exists 


\begin{tabular}{|llllllll|}
\hline & $\begin{array}{l}\text { Altitude } \\
(\mathrm{m} \text { asl })\end{array}$ & $\begin{array}{l}\text { Width } \\
(\mathrm{m})\end{array}$ & $\begin{array}{l}\text { Depth } \mathrm{H}^{1} \\
(\mathrm{~m})\end{array}$ & $\sin \alpha^{2}$ & $\begin{array}{l}\varnothing \text { Ice velocity } \\
\text { normal flow } \\
\left(\mathrm{ma}^{-1}\right)\end{array}$ & $\begin{array}{l}\varnothing \text { Ice velocity } \\
\text { minimal flow } \\
\left(\mathrm{ma}^{-1}\right)\end{array}$ & $\begin{array}{l}\varnothing \text { Ice velocity } \\
\text { maximal flow } \\
\left(\mathrm{ma}^{-1}\right)\end{array}$ \\
\hline Q1 & 4150 & 910 & 125 & 0.112 & 11.5 & 7.9 & 16.0 \\
Q2 & 4050 & 530 & 100 & 0.152 & 16.8 & 11.5 & 23.3 \\
\hline
\end{tabular}

Uncertainties:

${ }^{1}+5 \mathrm{~m}$ due to moraine erosion

${ }^{2} \pm 5 \%$ (uncertainties in surface reconstruction)

${ }^{3}$ uncertainties in ${ }^{1)},{ }^{2)}$ and $\pm 20 \%$ flow parameters

Tab. 4: Geometry and mass flux in the cross sections (ablation zone) of the paleoglacier Wara Wara (Fig. 1)

Kennzahlen der Querschnitte im Ablationsgebiet des ehemaligen Gletschers Wara Wara (Fig. 1)

Géométrie et flux de glace dans les coupes transversales (zone d'ablation) du paléoglacier Wara Ware (Fig. 1)

between the glaciers in the east (ELAs at $4250 \mathrm{~m}$ ), west (ELAs at $4550 \mathrm{~m}$ ) and middle (ELAs at $4350 \mathrm{~m}$ ) of the research area. Assuming synchronous glacier advances, these results can be interpreted as follows:

- If precipitation is taken as a constant over the whole study area, the temperature depression is highest in the western part and lowest in the eastern part (differences of up to $2.5^{\circ} \mathrm{C}$ ). In this small area, this type of temperature pattern seems very unlikely.

- If a uniform temperature decrease over the study area is assumed, the eastern part would need a much higher increase in precipitation than the middle and western parts (plus $300-800 \mathrm{~mm}$ annual precipitation).

Modeling results with a lower lapse rate lead to similar conclusions. Temperature-precipitation-«solution areas» (Fig. 5) generally move downward by about $0.5^{\circ} \mathrm{C}$. It is thus clear that there is no linear relationship between $T$ and $P$. The solution scenario lines become less inclined with the change from colddry conditions to warm-wet conditions. Therefore, at $\left[\mathrm{dT}=-9^{\circ} \mathrm{C} ; \mathrm{dP}=-200 \mathrm{~mm}\right]$, a further decrease in precipitation of $100 \mathrm{~mm}$ requires a decrease in temperature of about $3^{\circ} \mathrm{C}$. In contrast, at $\left[\mathrm{dT}=-6^{\circ} \mathrm{C} ; \mathrm{dP}=\right.$ $+200 \mathrm{~mm}$ ], an increase in temperature of about $3^{\circ} \mathrm{C}$ has to be compensated by an increase in precipitation of more than $700 \mathrm{~mm}$ ! Glaciers in the lower left of Fig. 5 reacted very sensitively to changes in precipitation because it was cold enough. Glaciers in the upper right, on the other hand, reacted especially sensitively to changes in temperature because the climate was wet enough. This pattern can be explained by the fact that under cold climatic conditions, precipitation falls exclusively as snow: in a generally warm climate, small changes in temperature may have a huge effect on accumulation as precipitation falls either as snow or rain.

\subsection{D-Results}

As mentioned above, only one paleoglacier fulfilled all requirements, enabling the exact computation of its flow behavior (Wara Wara, Fig.1). Fig. 6 shows the bed and modeled surface topography along its central flowline. The 3D-modeling approach (Table 5) shows similar results for both lapse rate scenarios. It is evident that a massive temperature decrease with annual precipitation reflecting present values led to the observed local last glaciation maximum at Wara Wara. The calculations respond very sensitively to small changes in slope and flow parameters. These uncertainties are listed in Table 5. Fig. 7 shows the annual mass balances of the paleoglacier Wara Wara with regards to mean, maximum and minimum ice flow through the calculated cross sections ( $\pm 20 \%$ flow parameters, $\pm 2.5 \mathrm{~m}$ thickness, $\pm 5 \%$ slope) with the lower lapse rate of $-0.53 \pm 0.106{ }^{\circ} \mathrm{C} / 100 \mathrm{~m}$. The maximum ice flow scenario is characteristic of a «cool-wet» climate $\left(\mathrm{dT}=-5^{\circ} \mathrm{C} ; \mathrm{dP}=+910 \mathrm{~mm}\right)$ whereas the minimum ice flow scenario reflects "cold-dry» climatic conditions $\left(\mathrm{dT}=-7.65^{\circ} \mathrm{C} ; \mathrm{dP}=+60 \mathrm{~mm}\right)$. There are clear seasonal differences in the computed mass balance (Fig. 8). During winter (April-September), net ablation is calculated over the whole glacier, even at elevations higher than $5000 \mathrm{~m}$ asl. Intensive solar radiation in combination with a dry windy climate leads to intensive sublimation. Respective values are higher than the accumulation of about $120 \mathrm{~mm}$ (most precipitation is deposited as snow). The low balance gradient in the ablation area reflects well the cold, dry climate. During summer (October-March), net accumulation dominates the glacier. In the annual mean the ELA is situated at $4250 \mathrm{~m}$ asl.

Basal shear stress was calculated for the upper (Q1, Table 4) and lower cross section, the values being between 0.773-0.855 bar, and 0.856-0.946 bar respectively. These values are not typical for either maritime 


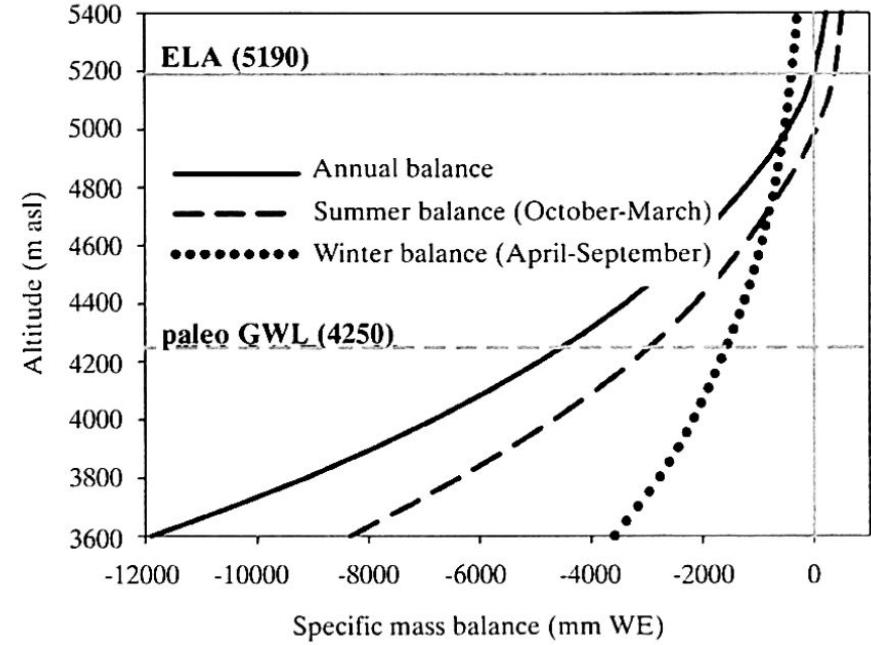

Fig. 4: Present annual and seasonal balance-elevation distribution in the highlands around Cochabamba The grey vertical line shows a mass balance of zero. The solid horizontal line represents the current ELA at $\sim 5190 \mathrm{~m}$ asl, the dashed horizontal line the paleo-ELA at $\sim 4250 \mathrm{~m}$ asl. Present climatic conditions at $3500 \mathrm{~m}$ asl are $7.0^{\circ} \mathrm{C}$ and $780-910 \mathrm{~mm}$ annual precipitation.

Gegenwärtige jährliche und saisonale Bilanz-HöhenVerteilung in der Cordillera nördlich von Cochabamba Répartition annuelle et saisonnière actuelle de l'équilibre-altitude dans la Cordillère au nord de Cochabamba

or continental type glaciers given the altitudinal range of the glacier (Maisch \& Haeberli 1982) and are, therefore in line with the suggested climate scenario.

After application of these results to the whole test area (Fig.1), taking isochronous and iso-thermal conditions for LLGM into account, the conclusion can be made that in comparison to today, precipitation was similar in the western part of the study area. In the middle part of the study area precipitation was greater by about $100 \mathrm{~mm}$, and in the eastern part, the difference was close to $200 \mathrm{~mm}$. This reflects a uniform temperature depression of about $6.5^{\circ} \mathrm{C}$ and confirms a NE-SW precipitation gradient during the LLGM.

\section{Paleoclimatic implications - discussion}

KuLL et al. (2003) show that glaciers in areas with annual precipitation values above about $800 \mathrm{~mm}$ are mainly controlled by temperature. In areas with less precipitation, humidity becomes the dominant parameter. Consequently, the varying chronology of glacier advances in the South American Andes can mostly be explained by their geographical location with respect to the atmospheric circulation systems. For example, in the dry western cordillera of northern Chile and southern Peru, glacier advances were caused by an increase of moisture supplied by the easterly tropical circulation during late glacial times (around 15-10 kyr B.P.). During the LGM (around 20 kyr B.P.), the climate in the Atacama Desert was too dry to allow massive glacier advances (GrosJEAN et al. 2001; Kull \& GrosJEAN 2000; Kull et al. 2002). In contrast, in the eastern Cordillera Oriental, massive glacier advances occurred during the LGM. Therefore, even under cold LGM conditions, the moisture supply was high enough to enable glacier advances (SELTZER et al. 2002).

The conclusions made here are in agreement with recent exposure age dates of moraines in the same study area (ZECH et al. 2006b), the results of Kull et al. (2003) for north-western Argentina, and those of Seltzer et al. (2002) for Bolivia. Following ZeCH et al. (2006b), glaciers substantially advanced at about $20 \mathrm{kyr}$, minor advances occurred around 12 and 10 kyr B.P.. Glacier advances at about $20 \mathrm{kyr}$ B.P. (LGM) point to a temperature sensitivity of glaciers on the eastern slope of the Cordillera Oriental. Moisture supply from the eastern lowlands seems to have been sufficient even during cold phases. The modeled climate scenario with a massive cooling of about -5.0 to $-7.65^{\circ} \mathrm{C}$ also suggests that

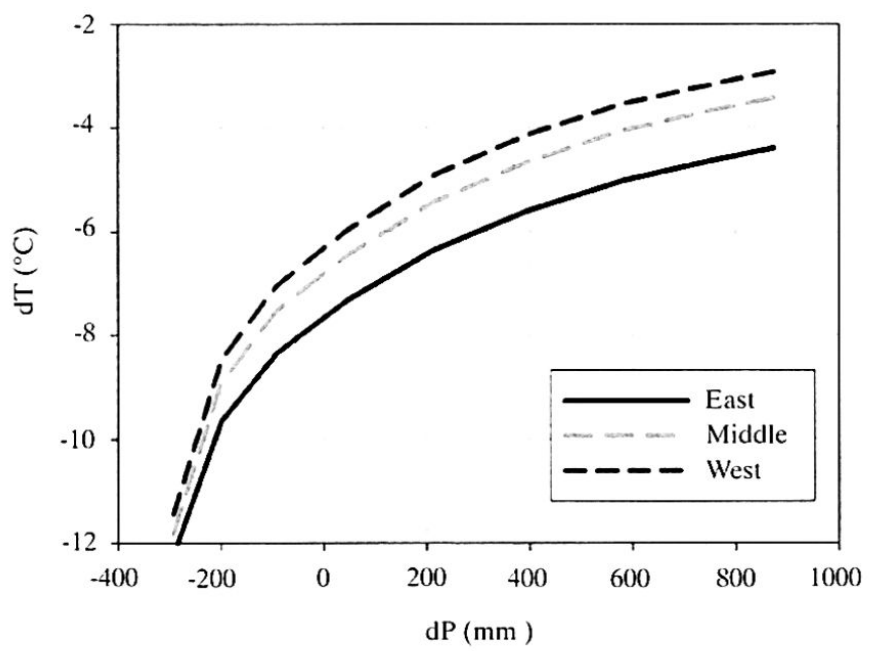

Fig. 5: Results of the 2D-modeling approach calculated with a lapse rate of $-0.7+/-0.15^{\circ} \mathrm{C} / 100 \mathrm{~m}$

The areas show possible temperature-precipitation combinations that lead to zero mass balance for the paleoglaciers. The different grey scales match with the three zones West(bright), Middle (dark), and East (medium) into which the research area has been divided (Fig. 1) and represent average results. It shows that the warmer the climate, the higher the precipitation has to be to keep the glacier at zero balance and to produce an ELA at the observed altitude.

Resultate der $2 D$-Modellierung mit einem Höhengradienten der Temperatur von $-0.7+/-0.15^{\circ} \mathrm{C} / 100 \mathrm{~m}$ Résultats de la modélisation $2 D$ avec un gradient d'altitude de la température de $-0.7^{\circ} \mathrm{C}+/-0.15^{\circ} \mathrm{C} / 100 \mathrm{~m}$ 


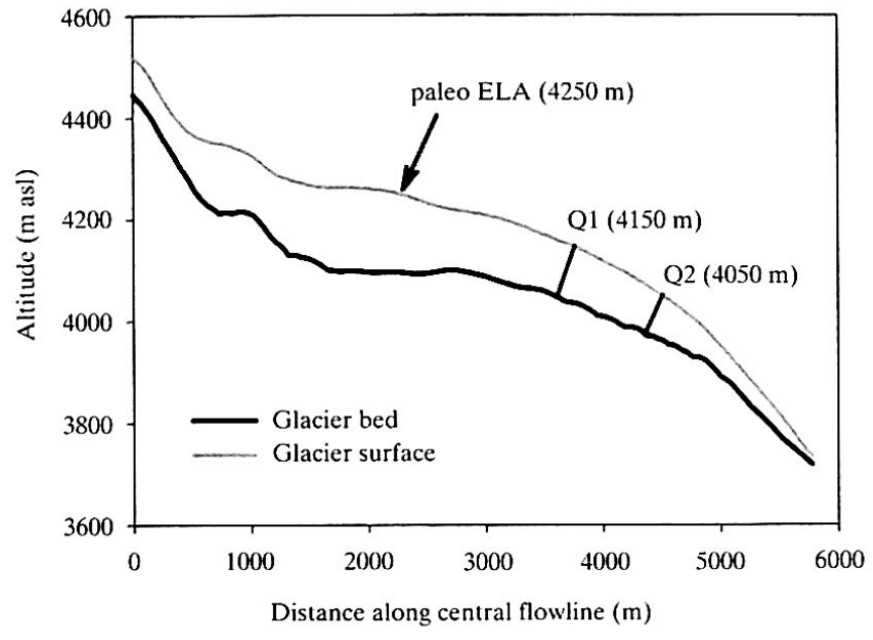

Fig. 6: Glacier bed and modeled surface topography (central flow line) of paleoglacier Wara Wara

Gletscherbett und modellierte Oberflächentopographie entlang der zentralen Fliesslinie des ehemaligen Gletschers Wara Wara

Lit glaciaire et topographie de surface modélisée le long de la ligne centrale d'écoulement du paléoglacier Wara Wara

maximum advances occurred during full glacial times of marine isotope stage (MIS) 2 (25-18 kyr B.P.). Obviously, precipitation was not the crucial key parameter triggering maximum glacier advances on the eastern slope of the Cordillera Oriental. Maximum glaciation was mainly controlled by temperature.

Furthermore, the results show that moisture and convection still reached the easternmost parts of the Cordillera Oriental during cold periods. This is also shown by Placzek et al. (2006). They dated a shallow lake phase between 24-20.5 kyr B.P. in the southern Altiplano of Bolivia. The west-east gradient in precipitation was stronger than today and suggests a dominant north-eastern advection of moisture to the research area. This implies that summer humidity, like today, was the main source of precipitation. The steeper gradient may point to lower condensation levels and/or a weakened easterly upper tropospheric circulation preventing convection and moisture from flowing as often as today over the first mountain ridges. This would explain why only the western part of the study area is influenced (see Fig. 1, 2D-results). A weaker seasonality at 10 kyr B.P. (Bush \& Silman 2004) could also have softened easterly summer moisture advection. A higher frequency of south-easterly cold air outbreaks («surazo» in Bolivia) with a subsequent enhancement of winter precipitation in the lowlands is not expected to have significantly influenced the research area due to the fact that these cold air masses do not reach the east Andean highlands. Аввотт et al. (2003) analyzed several sediment cores from lakes in the Cordillera Oriental. They dated the deglaciation to about 10 kyr B.P. Mouguiart \& LedRu (2003) reconstructed climatic conditions from paleovegetation on the east-

\begin{tabular}{|c|c|c|}
\hline & $\Delta \mathrm{T}\left({ }^{\circ} \mathrm{C}\right)$ & $\Delta \mathrm{P}(\mathrm{mm})$ \\
\hline $\begin{array}{l}\text { Lapse rate: }-0.7+/-0.15 \\
\left({ }^{\circ} \mathrm{C} / 100 \mathrm{~m}\right)\end{array}$ & -6.37 & +230 \\
\hline Lapse rate: $-0.53+/-0.106\left({ }^{\circ} \mathrm{C} / 100 \mathrm{~m}\right)$ & -6.36 & +340 \\
\hline Uncertainties: & $\mathrm{T}\left({ }^{\circ} \mathrm{C}\right)$ & $\mathrm{P}(\mathrm{mm})$ \\
\hline $\begin{array}{l}\text { Ice thickness } \pm 2.5 \mathrm{~m}^{1} \\
\text { Flow parameters } \pm 5 \% \\
\text { Flow parameters } \pm 20 \% \\
\sin \alpha \pm 5 \%\end{array}$ & $\begin{array}{l} \pm 0.25 \\
\pm 0.17 \\
+0.59 /-0.69 \\
+0.44 /-0.51\end{array}$ & $\begin{array}{l} \pm 0.10 \\
\pm 0.45 \\
+190 /-170 \\
\pm 130\end{array}$ \\
\hline Total uncertainties: final scenario & $+1.38 /-1.28$ & $+570 /-280$ \\
\hline
\end{tabular}

' «Mean» is taken as the average of maximum $(5 \mathrm{~m})$ and minimum cross section that was measured.

${ }^{2}$ Considering single uncertainties, the effect on the solution scenario is symmetric. Summarizing all values to a total uncertainty makes the solution scenario asymmetric due to the non-linear temperature-precipitation-relationships (see Fig 5).

Tab. 5: Results of the dynamical ice flow (3D-modeling) of the paleoglacier Wara Wara Resultate der 3D-Modellierung des ehemaligen Gletschers Wara Wara Résultats de la modélisation $3 D$ des flux de glace du paléoglacier Wara Wara 


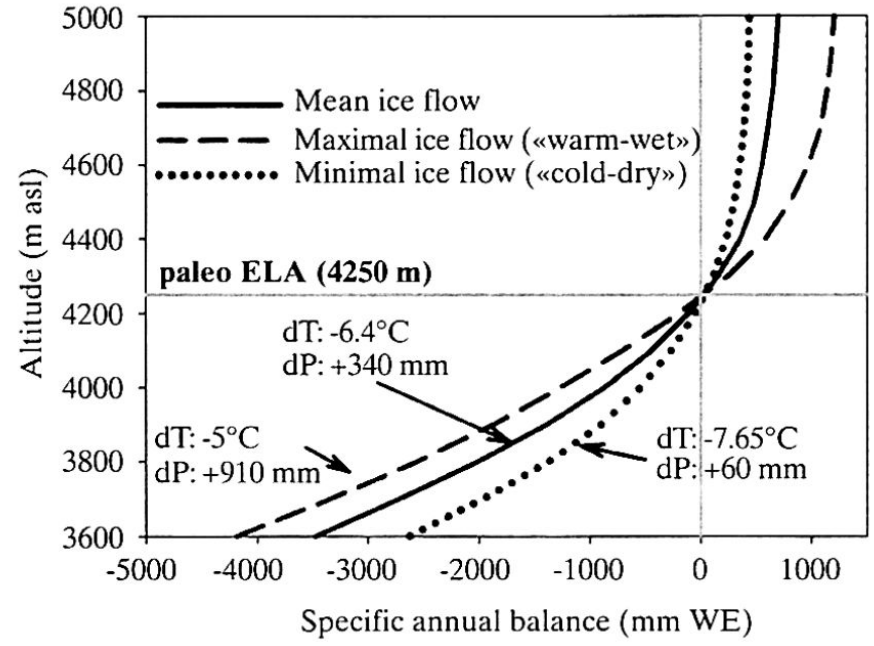

Fig. 7: Modeled balance-elevation distributions for the paleoglacier Wara Wara

The three graphs show modeled climate scenarios with mean (solid), maximum (dashed) and minimum (dotted) ice flow through the defined cross sections. All scenarios lead to the same ELA. The horizontal grey line is the paleo-ELA at $4250 \mathrm{~m}$ asl.

Modellierte Bilanz-Höhen-Verteilung des ehemaligen Gletschers Wara Wara

Modélisation de l'équilibre-altitude du paléoglacier Wara Wara

ern slope of the Cordillera Oriental in Bolivia. Their results indicate a relatively dry LGM, a wet late glacial period and drier climatic conditions at the onset of the Holocene. This climatic history may explain why different glacier advances are associated with different glacier geometries. Mapping of former glacier extents (Fig.1) points to a broad range of observed AAR's and various advances indicated by different moraine stages. This agrees with maximum advances under "cold-dry" (low AAR) conditions during the LGM, followed by late glacial «warm-wet» advances (high AAR) as also observed in north-western Argentina (KuLL et al 2003). Chronology, geometry and moraine stratigraphy in the region therefore need further attention in order to be able to discern which glacier advances were driven by what climatic conditions and when.

\section{Conclusions}

A glacier-climate model was used to reconstruct paleoclimatic conditions that triggered the local last glaciation maximum on the eastern slope of the Cordillera Oriental near the city of Cochabamba $\left(17^{\circ} 15^{\prime} \mathrm{S} / 66^{\circ} 15^{\prime} \mathrm{W}\right)$, Bolivia. The results point primarily to a temperature sensitivity of the glaciers in the study area. In order to reach the maximum extent, the most likely paleoclimate scenario suggests that annual mean temperatures were lower by $6.5(+1.4,-1.3)^{\circ} \mathrm{C}$ while annual precipitation was about $300 \mathrm{~mm}$ higher than today. Humidity was delivered as today by north-easterly advection of moist air in summer to the research area. The steeper west-east gradient in the past probably suggests a lower condensation level in the atmosphere, in agreement with the calculated massive temperature depression. Low shear stress values below 1 bar and an AAR of 0.59 confirm that the maximum glacial advance was not primarily driven by a precipitation increase under a «warm-wet» climate scenario. On the contrary, the results suggest a «cold-humid» climate as most likely for the observed maximum glacier advances in the region.

The results presented here from theWara Wara paleoglacier suggest that maximum glacier advances on the eastern slope of the Cordillera around Cochabamba occurred during full glacial times of MIS 2 (25-18 kyr B.P.). Subsequent minor advances occurred likely during relatively warm and especially wet periods in late glacial times.

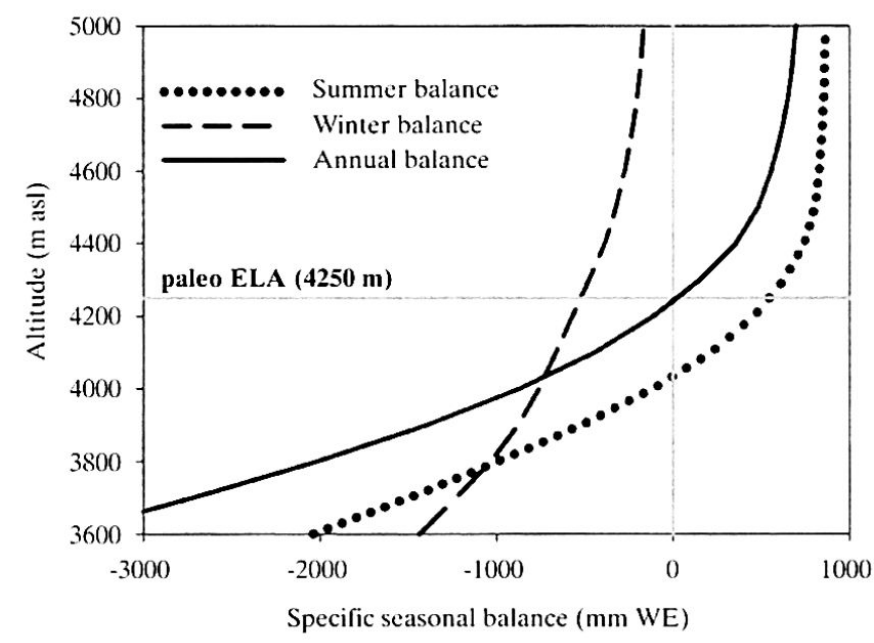

Fig. 8: Modeled seasonal balance-elevation distributions for the paleoglacier Wara Wara

The solid line is the calculated annual balance with mean ice flow (see Fig. 7). The differences between the winter and summer balances are substantial. This is an indication that during winter, the whole glaciated area is influenced by ablation. Further, the low winter balance gradients of $\sim 1.5 \mathrm{~kg}^{*} \mathrm{~m}^{2 *} \mathrm{~m}^{-1}$ indicate "cold-dry» (sublimation dominated) climatic conditions, whereas the summer season is characterized by «wet-warm» (melt intensive) climatic conditions.

Modellierte saisonale Bilanz-Höhen-Verteilungen für den ehemaligen Gletscher Wara Wara

Modélisation de l'équilibre-altitude saisonnier du paléoglacier Wara Wara 


\section{Acknowledgements}

This study is part of the Swiss NSF project «Paleoecology of Eastern Bolivia» (NF 200020-105228/1). Meteorological data was provided by the «Centro de Levantamiento Aeroespaciales y Aplicaciones SIG» (Director Ing. Enrique Fernandez) and the «Grupo Técnico Recursos Naturales» (Ing. Holger Utermöhlen), Cochabamba, Bolivia.

\section{Literature}

Aвbott, M.B., Wolfe, B.B., Wolfe, A.P., Seltzer, G.O., Aravena, R., Mark, B.G., Polissar, P.J., Rodbell, D.T., Rowe, H.D. \& M. VuilLe (2003): Holocene paleohydrology and glacial history of the Central Andes using multiproxy lake sediment studies. - In: Palaeogeography, palaeoclimatology, palaeoecology 194: 123-138.

Ammann, C. (1996): Aktuelle Niederschlagsmuster. - In: Jenny, B., Kammer, K. \& C. Ammann: Climate change in den trockenen Anden. - Geographica Bernensia G46: 81-127.

Ammann, C., Jenny, B., Kammer, K. \& B. Messerli (2001): Late Quaternary glacier response to humidity changes in the arid Andes of Chile (18-29 $\mathrm{S})$. - In: Palaeogeography, palaeoclimatology, palaeoecology 172: 313-326.

Baker, P.A., Seltzer, G.O., Fritz, S.C., Dunbar, R.B., Grove, M.J., TAPia, P.M., Cross, S.L., Rowe, H.D. \& J.P. Broda (2001): The history of South American tropical precipitation for the past 25,000 years. - In: Science 291, 5504: 640-643.

Betancourt, J.L., Latorre, C., Rech, J.A., Quade, J. \& K.A. RyLANDER (2000): A 22,000-year record of monsoonal precipitation from northern Chile's Atacama Desert. - In: Science 289, 5484: 1542-1546.

BudD, W.F. (1969): The dynamics of ice masses. - = Australian National Antarctic Research Expeditions Scientific Report 108.

BuDyкo, M.I. (1974): Climate and life. - New York: Academic Press.

Bush, M.B. \& M.R. Silman (2004): Observations on late Pleistocene cooling and precipitation in the lowland neotropics. - In: Journal of Quaternary science 19, 7: 677-684.

Caviedes, C.N. (1990): Rainfall variation, snowline depression and vegetational shifts in Chile during the Pleistocene. - In: Climatic change 16: 9-114.

Clapperton, C.M., Clayton, J.D., Benn, D.I., Marden, C.J. \& J. Argollo (1997): Late Quaternary glacier advances and palaeolake highstands in the Bolivian Altiplano. - In: Quaternary international 38-39: 49-59. Clayton, J.D. \& C.M. Clapperton (1997): Broad synchrony of a late-glacial glacier advance and the highstand of palaeolake Tauca in the Bolivian Altiplano. - In: Journal of Quaternary science 12, 3: 169-182.

Colinvaux, P.A., de Oliveira, P.E., Moreno, J.E., Miller, M.C. \& M.B. Bush (1996): A long pollen record from Lowland Amazonia: forest and cooling in glacial times. - In: Science 274, 5284: 85-88.

EspizuA, L.E. (1999): Chronology of late Pleistocene glacier advances in the Rio Mendoza Valley, Argentina. - In: Global and planetary change 22, 1-4: 193-200.

Farrera, I., Harrison, S.P., Prentice, I.C., Ramstein, G., Guiot, J., Bartlein, P.J., Bonnefille, R., Bush, M., Cramer, W., von Grafenstein, U., Holmgren, K., Hooghiemstra, H., Hope, G., Jolly, D., Lauritzen, S.E., Ono, Y., PInot, S., STute, M. \& G. Yu (1999): Tropical climates at the last glacial maximum: a new synthesis of terrestrial palaeoclimate data. I. Vegetation, lake-levels and geochemistry. - In: Climate dynamics 15, 11: 823-856.

Grosjean, M., Geyh, M., Messerli, B. \& U. SchotTERER (1995): Late-glacial and early Holocene lake sediments, groundwater formation and climate in the Atacama Altiplano. - In: Journal of paleolimnology 14: 252-341.

Grosjean, M., van Leeuwen, J.F.N., van der KnaAP, W.O., Geyh, M.A., Ammann, B., Tanner, W., MesSerli, B., Nuñez, L.A., Valero-Garces, B.L. \& H. VEIT (2001): A 22,000 ${ }^{14} \mathrm{C}$ year BP sediment and pollen record of climate change from Laguna Miscanti $\left(23^{\circ} \mathrm{S}\right)$ northern Chile. - In: Global and planetary change 28. 1-4:35-51.

Hastenrath, S. (1984): The glaciers of Equatorial East Africa. - Dordrecht: D. Reidel Publishing Company. Heine, K. (2000): Tropical South America during the last glacial maximum: evidence from glacial, periglacial and fluvial records. - In: Quaternary international 72: 7-21.

Hostetler, S.W. \& P.U. Clark (2000): Tropical climate at the last glacial maximum inferred from glacier massbalance modeling. - In: Science 290, 5497: 1747-1750.

Kageyama, M., Harrison, S.P. \& A. Abe-Ouchi (2005): The depression of tropical snowlines at the last glacial maximum: What can we learn from climate model experiments? - In: Quaternary international 138-139: 202-219.

Kalnay, E., Kanamitsu, M., Kistler, R., Collins, W., Deaven, D., Gandin, L., Iredell, M., Saha, S., White, G., Woollen, J., Zhu, Y., Chelliah, M., Ebisuzaki, W., Higgins, W., Janowiak, J., Mo, K.C., Ropelewski, C., Wang, J., LeetmaA, A., Reynolds, R., Jenne, R. \& D. JOSEPH (1996): The NCEP/NCAR 40-year reanalysis project. - In: Bulletin of the American Meteorological Society 77: 437-471.

Klein, A.G., Seltzer, G.O. \& B.L. Isacks (1999): Modern and last local glacial maximum snowlines in the Central Andes of Peru, Bolivia, and northern Chile. - In: Quaternary science reviews 18, 1: 63-84.

KuLl, CH. (1999): Modellierung paläoklimatischer Verhältnisse, basierend auf der jungpleistozänen Vergletscherung - ein Beispiel aus den nordchilenischen Anden. - In: Zeitschrift für Gletscherkunde und Glazialgeologie 35, 1: 35-64. 
Kull, C. \& M. Grosjean (1998): Albedo changes, Milankovitch forcing, and late Quaternary climate changes in the Central Andes. - In: Climate dynamics 14: 871-881.

Kull, C. \& M. Grosjean (2000): Late Pleistocene climate conditions in the north Chilean Andes drawn from a climate-glacier model. - In: Journal of glaciology 46: 622-632.

Kull, C., Grosjean, M. \& H. Veit (2002): Modeling modern and late Pleistocene glacio-climatological conditions in the north Chilean Andes. - In: Climatic change 52:359-381.

Kull, C., Hänni, F., Grosjean, M. \& H. Veit (2003): Evidence of an LGM cooling in NW-Argentina $\left(22^{\circ} \mathrm{S}\right)$ derived from a glacier climate model. - In: Quaternary international 108: 3-11.

Maisch, M. \& W. HaEberLI (1982): Interpretation geometrischer Parameter von Spätglazialgletschern im Gebiet Mittelbünden, Schweizer Alpen. - In: Beiträge zur Quartärforschung in der Schweiz, Physische Geographie 1, Zürich: 111-126.

Mark, B.G., Harrison, S.P., Spessa, A., New, M., Evans, D.J.A. \& K.F. Helmens (2005): Tropical snowline changes at the last glacial maximum: a global assessment. - In: Quaternary international 138-139: 168-201. Markgraf, V., Baumgartner, T.R., Bradbury, J.P., Diaz, H.F., Dunbar, B., Luckman, B.H., Seltzer, G.O., Swetnam, T.W. \& R. Villalba (2000): Paleoclimate reconstruction along the Pole-Equator-Pole transect of the Americas (PEP 1). - In: Quaternary science reviews 19, 1-5: 125-140.

MöLG, T. (2002): Modellierung der kurzwelligen Einstrahlung mit GIS am Beispiel eines tropischen Hochgebirges. - In: Strobl, J., Blaschke T. \& G. GriesebNER (Hrsg): Beiträge zum AGIT-Symposium Salzburg 2002. - Berlin, Heidelberg: Wichmann: 347-356.

Mölg, T., Georges, C. \& G. Kaser (2003): The contribution of increased incoming shortwave radiation to the retreat of the Rwenzori glaciers, East Africa, during the 20th century. - In: International journal of climatology 23: 291-303.

Mourguiart, P. \& M.-P. Ledru (2003): Last glacial maximum in an Andean cloud forest environment (Eastern Cordillera, Bolivia). - In: Geology 31, 3: 195198.

National Climatic Data Center (NCDC) (1980): Integrated global radiosonde archive. - http://www.ncdc. noaa.gov/oa/climate/igra/index.php?name=visualization NCDC 5.8.2005.

Oerlemans, J. (1997): A flowline model for Nigardsbreen, Norway: projection of future glacier length based on dynamic calibration with the historic record. - In: Annals of glaciology 24:382-389.

Pinot, S., Ramstein, G., Harrison, S.P., Prentice, I.C., Guiot, J., Stute, M. \& S. Joussaume (1999): Tropical paleoclimates at the last glacial maximum. Comparison of Paleoclimate Modeling Intercomparison
Project (PMIP) simulations and paleodata. - In: Climate dynamics 15: 857-874.

Placzek, C., Quade, J. \& P.J. Patchett (2006): Geochronology and stratigraphy of late Pleistocene lake cycles on the southern Bolivian Altiplano. Implications of causes of tropical climate change. - In: Geological Society of America (GSA) Bulletin 118, 5: 515-532.

Sailer, R., Kerschner, H. \& A. Heller (1999): Threedimensional reconstruction of younger Dryas glaciers with a raster-based GIS. - Glacial geology and geomorphology 1999/rp01, http://ggg.qub.ac.uk/papers/ frame.htm.

SCHÄвITZ, F. (2000): Vegetation and climate history on the eastern flank of the Sierra de Santa Victoria, Jujuy Province, NW-Argentina (first results). - In: Zentralblatt für Geologie und Paläontologie (Teil 1) 7, 8: 969989.

Seltzer, G.O. (1992): Late Quaternary glaciation of the Cordillera Real, Bolivia. - In: Journal of Quaternary science 7, 2: 87-98.

Seltzer, G.O. (1994): A lacustrine record of late Pleistocene climatic change in the subtropical Andes. - In: Boreas 23: 105-111.

Seltzer, G.O., Rodbell, D.T., Baker, P.A., Fritz, S.C., TaPia, P.M., Rowe, H.D. \& R.B. Dunbar (2002): Early warming of tropical South America at the last glacialinterglacial transition. - In: Science 296, 5573: 16851686.

Sicard, J.E., Wagnon, P., Gallaire, R., Francou, B., Ribstein, P., Pouyaud, B. \& H. Baldivieso (1998): Mesures météorologiques, hydrologiques et glaciologiques sur le glacier du Zongo, année hydrologique 1996-97. - In: Informe 57, Office de la recherche scientifique et technique outre-mer (ORSTOM), La Paz: 119.

Stute, M., Forster, M., Frischrorn, H., Serejo, A., Clark, J.F., Schlosser, P., Broecker, W.S. \& G. Bonani (1995): Cooling of lowland tropical Brazil $\left(5^{\circ} \mathrm{C}\right)$ during the last glacial maximum. - In: Science 269:379-383.

Sylvestre,F.,Servant, M.,Servant-Vildary,S.,Causse, C., Fournier, M. \& J.P. YBert (1999): Lake-level chronology on the southern Bolivian Altiplano $\left(18^{\circ}-23^{\circ} \mathrm{S}\right)$ during late-glacial time and the early Holocene. - In: Quaternary research 51, 1: 54-66.

Thompson, L.G., Davis, M.E., Mosley-Thompson, E., Sowers, T.A., Henderson, K.A., Zagorodnov, V.S., Lin, P.-N., Mikhalenko, V.N., CAmpen, R.K., Bolzan, J.F., Cole-Dai, J. \& B. Francou (1998): A 25'000-year tropical climate history from Bolivian ice cores. - In: Science 282: 1858-1864.

Thompson, L.G., Mosley-Thompson, E., Davis, M.E., Lin, P.-N., Henderson, K. \& T.A. Mashiotta (2003): Tropical glacier and ice core evidence of climate change on annual to millennial time scales. - In: Climatic change 59: 137-155.

Vuille, M. (1996): Zur raumzeitlichen Dynamik von Schneefall und Ausaperung im Bereich des südlichen 
Altiplano, Südamerika. - = Geographica Bernensia G45, Bern.

Wagnon, P., Ribstein, P., Francou, B. \& B. Pouyaud (1999): Annual cycle of energy balance of Zongo glacier, Cordillera Real, Bolivia. - In: Journal of geophysical research 104: 3907-3923.

Wyrwoll, K.H., Dong, B. \& P. VAldes (2000): On the position of southern hemisphere westerlies at the last glacial maximum: an outline of AGCM simulation results and evaluation of their implications. - In: Quaternary science reviews 19, 9:881-898.

ZeCH, R., Kull, C. \& H. Veit (2006a): Late Quaternary glacial history in the Encierro Valley, northern Chile $\left(29^{\circ} \mathrm{S}\right)$, deduced from ${ }^{10} \mathrm{Be}$ surface exposure dating. - In: Palaeogeography, palaeoclimatology, palaeoecology 234: 277-286.

ZeCH, R., Kull, C. \& H. VeIt (2006b): Expositionsdatierung in den Zentralen Anden: quartäre Gletscherund Klimarekonstruktion mittels in situ ${ }^{10} \mathrm{Be}$. - In: Geographica Helvetica (this issue).

Zipprich, M., Reizner, B., Zech, W., Stingel, H. \& H. VEIT (2000): Upper Quaternary landscape and climate evolution in the Sierra de Santa Victoria (north-western Argentina) deduced from geomorphologic and pedogenic evidence. - In: Zentralblatt für Geologie und Paläontologie (Teil 1) 7, 8: 997-1011.

\section{Abstract: Temperature reduction and local last glaciation maximum (LLGM). The example of the east-Andean Cordillera around Cochabamba, Bolivia $\left(17^{\circ} \mathrm{S}\right)$}

This study presents results from a glacier-climate model that reconstructed glacio-climatological conditions during the last local glaciation maximum (LLGM) in the Cordillera to the north of Cochabamba $\left(17^{\circ} 15^{\prime} \mathrm{S}, 66^{\circ} 15^{\prime} \mathrm{W}\right)$, Bolivia. Results emphasize the temperature-sensitivity of glaciers on the eastern slope of the Cordillera Oriental. Maximum glacier advances appear to have been caused by a massive cooling of about $6.5^{\circ} \mathrm{C}$, while annual precipitation was about $300 \mathrm{~mm}$ higher than today $(850 \mathrm{~mm} / \mathrm{yr})$. Modeling results indicate maximum glacial advances during cold phases such as MIS 2 (25-18 kyr B.P.) and minor advances during late glacial cool events (12-10 kyr B.P.). This chronology is supported by exposure age dating results. Further evidence may be found in the low AAR-values (accumulation area ratio) which indicate low mass balance gradients and therefore cold climate conditions. Modeled basal shear stresses smaller than 1 bar exclude extremely «cold-dry" or "warm-wet" conditions. The spatial pattern of regional paleo-ELA's (equilibrium line altitude), with higher ELA's in the western part of the study area, reflects a strong east-west gradient in paleoprecipitation. Easterly summer precipitation is suggested to be the reason for this phenomenon.
These results are in agreement with other studies of the east-Andean slope, indicating temperature as the driving factor for maximum glacier advances in northwestern Argentina.

\section{Zusammenfassung: Temperaturreduktion und lokales letzteiszeitliches Gletschermaximum (LLGM). Ergebnisse aus der Cordillera de Cochabamba, Boli- vien $\left(17^{\circ} \mathrm{S}\right)$}

Ein Gletscher-Klima-Modell wurde angewendet, um die glazio-klimatologischen Bedingungen, die in der Cordillera Oriental nördlich der Stadt Cochabamba $\left(17^{\circ} 15^{\prime} \mathrm{S}, 66^{\circ} 15^{\prime} \mathrm{W}\right)$, Bolivien, zur letzten grossen Vereisung führten, zu rekonstruieren. Die Resultate bestätigen die Temperatur-Sensitivität der Gletscher am Ostabhang der Cordillera Oriental. Die Gletschervorstösse wurden durch einen starken Rückgang der Jahrestemperatur von $6.5^{\circ} \mathrm{C}$ verursacht, während der Jahresniederschlag im Vergleich zu heute nur um $\sim 300 \mathrm{~mm}$ erhöht war. Auf Grund dieser modellierten Temperaturreduktion bestätigt sich die Annahme, dass die Vorstösse während Kältephasen wie MIS 2 (25-18 kyr B.P.) oder spätglazialen Kälteereignissen (12-10 kyr B.P.) stattfanden. Diese Befunde werden durch Expositionsalterdatierungen unterstützt. Die rekonstruierten glaziologischen Parameter stimmen ebenfalls gut mit den modellierten Klimabedingungen überein. So weisen die tiefen AAR-Werte (accumulation area ratio) auf tiefe Bilanzgradienten, kalte Klimabedingungen und damit relativ lange Gletscherzungenbereiche hin. Die modellierten basalen Scherspannungen zwischen 0.77 und 0.95 bar schliessen extrem «kalt-trockene» oder «warm-feuchte» Klimabedingungen aus. Das räumliche Muster der einstigen Gleichgewichtslinien (GWL) mit tieferen GWL im Osten und höheren GWL im Westen bezeugen einen steilen Ost-West-Gradienten der ehemaligen Niederschläge. Deshalb kann davon ausgegangen werden, dass aus dem Tiefland im Nordosten stammende Sommerniederschläge auch damals den grössten Teil der Niederschläge ausmachten.

Die Resultate stimmen gut mit vorherigen Studien am Anden-Ostabhang (Nordwestargentinien) überein, in denen die Temperatur als der entscheidende Faktor für Gletschervorstösse erkannt wurde.

\section{Résumé: Diminution de température et dernier maximum glaciaire local (LLGM). L'exemple de la Cordillère andine de Cochabamba en Bolivie $\left(17^{\circ} \mathrm{S}\right)$} Cette étude présente les résultats d'un modèle appliqué à la reconstitution des conditions glaciaires et climatologiques de la dernière glaciation dans l'est de la Cordillère des Andes, au nord de la ville de Cochabamba en Bolivie $\left(17^{\circ} 15^{\prime} \mathrm{S}, 66^{\circ} 15^{\prime} \mathrm{W}\right)$. Les résultats confirment que les glaciers sont très sensibles aux changements de températures sur le versant oriental de la Cordillère. 
Les avancées glaciaires ont été causées par une baisse de la température annuelle d'environ $6,5^{\circ} \mathrm{C}$, tandis que les précipitations annuelles étaient supérieures d'environ $300 \mathrm{~mm}$ aux niveaux actuels. Les résultats de la modélisation indiquent que l'avancée glaciaire maximum s'est faite durant les phases froides comme celle de MIS 2 (25-18 kyr B.P.), alors que les avancées mineures ont eu lieu durant les derniers âges glaciaires (12-10 kyr B.P.). Cette chronologie est confirmée par des datations d'âge d'exposition. Les paramètres glaciaires reconstruits sont aussi en bonne conformité avec les conditions climatologiques modélisées. Les valeurs faibles de l'AAR (accumulation area ratio) indiquent des gradients d'équilibre bas, des conditions climatologiques froides et des langues glaciaires relativement longues. Les tensions de cisaillement basales modélisées de 0,77 et 0,95 bar permettent d'exclure des conditions climatologiques extrêmement «froidesarides» ou «chaudes-humides». Le modèle spatial des anciennes lignes d'équilibre, caractérisé par des lignes plus basses à l'est et plus hautes à l'ouest, est le signe d'un gradient est-ouest des paléoprécipitations, peutêtre lié à des précipitations précoces et estivales.

Les résultats concordent avec des études antérieures effectuées sur le versant oriental des Andes (au nordouest de l'Argentine) dans lesquelles la température constitue le facteur crucial des avancées glaciaires.

Dipl.-Geogr. Samuel Imhof, Dipl.-Geogr. Jan-Hendrik May, Prof. Dr. Heinz Veit, Geographical Institute, University of Berne, Hallerstrasse 12, CH-3012 Berne, Switzerland.

e-mail:

sam_imhof@gmx.ch

may@giub.unibe.ch

veit@giub.unibe.ch

Dr. Christoph Kull, PAGES IPO, Sulgeneckstrasse 38, CH-3007 Berne, Switzerland.

e-mail: kull@pages.unibe.ch

Prof. Dr. Martin Grosjean, NCCR Climate Management Centre, Erlachstrasse 9a, CH-3012 Berne, Switzerland.

e-mail: grosjean@giub.unibe.ch

\section{Manuskripteingang/received/manuscrit entré le}

15.2.2006

Annahme zum Druck/accepted for publication/accepté pour l'impression: 30.6 .2006 